American Journal of Agricultural and Biological Sciences 6 (3): 403-409, 2011

ISSN 1557-4989

(C) 2011 Science Publications

\title{
Rising Food Insecurity: Dimensions in Farm Households
}

\author{
${ }^{1}$ Okezie Chukwukere Austin, ${ }^{1}$ Aloysius Chidi Nwosu \\ and ${ }^{2}$ Amir Hussin Baharuddin \\ ${ }^{1}$ Department of Agricultural Economics, \\ Michael Okpara University of Agriculture, Umudike, Nigeria \\ ${ }^{2}$ Department of Economics, School of Social Sciences, \\ University Sains Malaysia, Penang, Malaysia
}

\begin{abstract}
Problem statement: Nigeria runs the risk of slowing further progress toward the achievement of MDG-1 to eradicate extreme hunger and poverty; the fourth goal, to reduce child mortality since over $30 \%$ of child deaths are attributable to malnutrition and the fifth goal relating to reduction in maternal mortality. This study evaluated the manifestation of food insecurity in households in Abia State, Nigeria. Approach: Systematic sampling was adopted in selecting households from the three geopolitical zones in the state. Primary and secondary data were used in the study. Data collection involved the use of structured questionnaires. Food intake, height and weight measures of children were taken Data analysis in involved the use of qualitative and quantitative methods. Results: Domestic food production is increasing but demand remained above production. The shortfall along with food import is on the increase. The composite consumer price index for food has continued to rise over the years. Logistic results show that income significantly reduced exposure to food insecurity while household size was an important determinant of food security. Children were more exposed to the incidence of growth retardation and stunting with increasing household size. Birth order increases the incidence of stunting. As more children come into the family there is increasing marginalization of the subsequent ones. Conclusion: Food insecurity is a developmental challenge in Nigeria. The country is characterized by high food imports and declining productivity of agriculture. Malnutrition is widespread especially among children in rural Nigeria. The study recommends family planning education to stern the over bloated population.
\end{abstract}

Key words: Food insecurity, malnutrition, farm, households

\section{INTRODUCTION}

The internal political dimension of food security became glaring during and immediately after the Second World War. Food became an instrument of power and Government must be concerned with how to raise its production (Ghaly and Alkoaid, 2010). Food is the most fundamental human need. Adequate nutrition has been globally recognized as a fundamental human right. Ideally, the whole population should have access to sufficient quantity and quality of food at all times. To guarantee access to food in the country, people should have adequate resources, either to produce food or to obtain it in exchange for other things (Akinyele, 2009; Jampawai et al., 2011). Nigeria is still characterized by high reliance on food imports. Malnutrition is widespread in the entire country and rural areas are especially vulnerable to chronic food shortages, malnutrition, unbalanced nutrition, erratic food supply, poor quality foods, high food costs and even total lack of food. This phenomenon cuts across all age groups and categories of individuals in the rural areas (Abdullateef and Ijaiya, 2010). There is a high level of malnutrition among children in rural Nigeria; the figures differ with geopolitical zones, with 56 percent reported in a rural area of South West and 84.3 percent in three rural communities in the northern part of Nigeria (Okwu et al., 2008; Oluwatayo, 2008). Nationally, the overall prevalence of stunting, wasting and underweight are 42.0 percent, 9 percent and 25 percent, respectively (Akinyele, 2009).

Food insecurity ranks the topmost among developmental problem facing Nigeria. The level of food insecurity has continued to rise steadily since the 1980s. It rose from about $18 \%$ in 1986 to about $41 \%$ in 2004 (Sanusi et al., 2006). Food security refers to the

Corresponding Author: Okezie Chukwukere Austin, Department of Agricultural Economics, Michael Okpara University of Agriculture, Umudike, Nigeria 
condition in which all people, at all times, have physical, social and economic access to sufficient, safe and nutritious food that meets their dietary needs and preferences for an active and healthy life (Iraj, 2009). Food availability, stability of supplies and food access are related determinants of food security. At the household level, food security implies an adequate access to food over time. This is possible when there is adequate food availability to the household and an adequate income capacity for the purchase of the available food. The problem of food and nutrition security in Nigeria has not been adequately and critically analyzed, despite various approaches at addressing the challenge. Given the high incidence of malnutrition, this study therefore, is an effort to ascertain the determinants of food insecurity at the household level in Nigeria.

\section{MATERIALS AND METHODS}

Study area: The survey was carried out in Abia State. Abia state is one of the thirty-six states of the Federal Republic of Nigeria. The state is located in the South East agro-ecological zones of Nigeria. Abia State lies between longitudes $7^{\circ} 00 \mathrm{E}$ and $8^{\circ} 00 \mathrm{E}$ and latitude $4^{\circ} 45^{1} \mathrm{~N}$ and $6^{\circ} 17^{1} \mathrm{~N}$ of the equator. The climate is tropical and humid all the year round. The rainy season ranges from March to October. The dry season occurs from November to February. The mean annual rainfall ranges from $2000 \mathrm{~mm}$ to $2500 \mathrm{~mm}$ with the southern areas receiving more than the northern areas. The temperature ranges between $22^{\text {oc }}$ minimum to $31^{\text {oc }}$ (maximum). The vegetation is predominantly lowland rainforest.

The population of the state was estimated at $2,297,928$ in 1991 . The population density is about 364 persons $/ \mathrm{km}^{2}$ with $63 \%$ in agricultural production.. Abia State comprises 17 Local Government Areas (L.G.A's) divided into three agricultural zones namely, Aba, Ohafia and Umuahia. In Aba zone, there are seven L.G.A's namely: Aba North, Aba South, Osisioma Ngwa, Obioma Ngwa North, Ukwa East, Ukwa West and Ugwunagbo. In Ohafia zone, there are five L.G.A's namely: Isuiukwuato, Ohafia, Bende, Arochukwu and Umunneochi. In Umuahia Zone, there are five L.G.A's namely: Umuahia North, Umuahia-South, Ikwuano, Isiala Ngwa North and Isiala Ngwa South.

Sample size and sampling procedure: A total of 120 farm households were chosen from the three agricultural zones of Abia State. A multi-stage stratified random sampling technique was adopted in selecting respondent households. First, all the 17 LGA's was listed to form a separate sampling frame from the three zones. Two Local Government Areas (LGA's) was purposively selected from each of the zones making a total of 6 LGA's, from the state. Secondly, from each of the 6 LGA's, four farming communities were purposively selected. The essence of the purposive selection is to ensure that rural communities were the major occupation is farming was selected. Thirdly, in each of the 24 communities/villages, a list of farm households were compiled with the assistance of village heads and resident ADP extension agents. From each village, 5 households were randomly selected for the study.

Data collection technique: A variety of techniques including observation, recall and direct measurement were used in the survey. Well-trained Enumerators who were resident Extension agents assisted in data collection. The pre-testing of questionnaire was undertaken thereafter the study households were visited bimonthly over a five-month period.

Analytical techniques and variables measurement: Two objective methods of food security measurement have been widely used in most food security studies (Shahateet, 2007). One is to estimate gross household production and purchases over time, estimate the growth or depletion of food stocks held over that period of time and presume that the food that has come into the household's possession and disappeared has been consumed. The other method is to undertake food consumption recall for individual members of a household or for the household as a whole and analyze each type of food mentioned for calorie content. In this study, a 7 day recall method was used. The food security line was the recommended daily per capita calorie intake of $2260 \mathrm{kcal}$. The household's calorie intake was obtained through the household's consumption and expenditure data. From the data we estimated the quantity of every food items consumed by the households in the 7 days period. The quantities were converted to gram and the calorie content was estimated by using the nutrient composition table of commonly eaten food in Nigeria. Per capita calorie intake was calculated by dividing estimated total household calorie intake by the household size after adjusting for adult equivalent using the consumption factors for age-sex categories. To get the household's daily per capita calorie intake we divided the household's per capita calorie intake by seven. A household whose daily per capita calorie intake is up to $2260 \mathrm{kcal}$ was regarded as food secure and those below $2260 \mathrm{kcal}$ were regarded as food insecure households. The food security status is bivariate, taking the value 1 for food secure households 
and 0 for food insecure households. On the basis of the above we estimated a binomial logistic regression model given that the dependent variable is dichotomous: 0 when the household is below the recommended calorie level (Food insecure) and 1 when above the recommended calorie level (Food secure).Predictor variables are a set of household socioeconomic characteristic status indicators. They contain both dichotomous and continuous variables. Let $\mathrm{Pj}$ denote the probability that the $\mathrm{j}$-th household is below the poverty line. We assume that $\mathrm{Pj}$ is a Bernouli variable and its distribution depends on the vector of predictors X, so that Eq. 1:

$P_{i}(X)=\frac{e^{\alpha+\beta_{x}}}{1+e^{\alpha+\beta_{x}}}$

where, $\beta$ is a row vector and $\alpha$ a scalar. The logit function to be estimated is then written as:

In $\frac{P}{1-P_{j}}=\alpha+\sum_{i} \beta_{i} X_{i j}$

The logit variable $\ln \left\{\mathrm{P}_{\mathrm{j}} /\left(1-\mathrm{P}_{\mathrm{j}}\right)\right\}$ is the natural $\log$ of the odds in favor of the household falling below the minimium level. Equation 2 is estimated by maximum likelihood method and the procedure does not require assumptions of normality or homoskedasticity of errors in predictor variables (Christopher et al., 2005).

Socio-demographic variables:

$\operatorname{AGE}_{\mathrm{H}}(+)=$ Age of household head (years)

$\operatorname{SEX}_{\mathrm{H}}(+)=1$ if household is male, 0 otherwise

$\operatorname{EDU}_{\mathrm{H}}(-)=$ Education of household head (years of formal education)

HHS (-) = Household size

INC (-) = Household income per capita $(\#=$ Nigeria currency)

FSC (-) = Farm size (hectares)

OCC $(+)=$ Occupation of household head 1 if farming, 0 otherwise

Statistics show that women and children are the most vulnerable to food insecurity as reflected by the high incidences in those categories. To determine the factors that expose children to the risk of malnutrition, anthropometric assessment of height and weight was undertaken to determine the manifestations of insecurity. The nutritional status of children between six months and six years of age was evaluated by means of anthropometric measurements: weight and health measurements related to each other and to the age of the child and compared with a standard reference population. As reference population statistics, the World Health Organization-US National Center for Health Statistic (WHO-NCHS) standards was used to identify the prevalence of malnutrition and the nutritional status of children in farming and nonfarming households. A z-score value of zero indicates a child who is "normal"; a negative z-score value indicates an anthropometric measurement below the one in the reference population; and a threshold level of below-2 z-score is commonly considered an indication of a serious nutritional problem. Three indicators used in the study are the height-for age (HAZ), weight-forage (WAZ) and the weight-for-height (WHZ) Z-scores. The Z-score values were calculated thus Eq. 3:

\section{Z-score = Actual Measurement -50 th \\ Percentile Standard/Standard \\ Deviation of 50th Percentile Standard}

The height-for-age (HAZ) is used to identify growth-retardation in children while the weight-for-age (WAZ) is used to identify under-weight or otherwise in children. The weight-for-height (WHZ) z-score is used to identify the abnormal condition of wasting or stunting in children. To further ascertain the factors that are associated with malnutrition in children, a multivariate regression was estimated for the three indicator of malnutrition. The model is stated thus Eq. 4:

$\mathrm{Y}=\mathrm{f}\left(\mathrm{AGE}_{\mathrm{C}}, \mathrm{NDS}, \mathrm{BOR}, \mathrm{SEX}_{\mathrm{C}}, \mathrm{PCFR}, \mathrm{HHS}\right)$

Where:

$\mathrm{Y}=$ Nutritional status of child (HAZ, WAZ, WHZ)

$\mathrm{AGE}_{\mathrm{C}}=$ Age of child (months)

ILL = Illness of the child measured in occurrence of illness within the last two weeks

$\operatorname{SEX}_{\mathrm{C}}=$ Male $=1$, Female $=0$

FEX = Per capita food expenditure

HHS = Household size (total number of persons in household)

$\mathrm{EDU}_{\mathrm{M}}=$ Education of mother (years of formal education)

BOR $=$ Birth order $($ First $=1$, Second $=2$ Third $=3$ )

\section{RESULTS}

Food security/insecurity situation in Rural Nigeria: Food insecurity is a situation that exists when all people, at all times, do not have physical, social and economic access to sufficient, safe and nutritious food that meets their dietary needs and food preferences for 
an active and healthy life. As seen Fig. 1, domestic food production is on the increase but demand remained above production. The short falls is increasing over the years and food imports equally. The figure summarizes food production, demand and short falls between 19912001. The agricultural sector is an admixture of subsistence and modern farming, while the industrial sector comprises modern business enterprises which co-exist with a large number of micro-enterprises employing less than 10 persons mainly located in the informal sector. The agricultural sector has not been able to fulfill its traditional role of feeding the population, meeting the raw material needs of industries and providing substantial surplus for export. Indeed, the contribution of the sector to total GDP has fallen over the decades, from a very dominant position of 55.8\% of the GDP in 1960-70 to $28.4 \%$ in 1971-80, before rising to $32.3,34.2$ and $40.3 \%$ during the decades 1981-90, 1991-2000 and 2001-2009, respectively.

Food access: Food access is a function of price of the commodities and income particularly of the head of household. This is particularly important in this case since households augment food from own production from market purchases (Mamoun et al., 2006). The consumer price index is indication of relative prices taken inflationary trends into consideration. Figure 2 show that the composite consumer price for food continued to increase over the years and that has contributed to the high incidence of malnutrition reported widely in various studies (Oluwatayo, 2008; Akinyele, 2009). The increases is more pronounced from 1989 following the introduction of the Structural Adjustment Program by the Babangida administration in 1986. Added to this is the global food crisis that led to the spiral increase in food crisis that is reminiscent in Fig. 2.

The Figure shows a rising trend in the consumer price index for all items and food. Abdullateef and Ijaiya (2010) observed that the relationship between all items and food price index calls for close scrutiny. This is because food price index accounted for a sizeable proportion of the all items consumer price index. This high food price index is a clear evidence of food insecurity.

Determinants of food insecurity at household level: The estimates of the logistic regression are shown in Table 1 . The logit model fitted the data well as shown by the relevant parameters. The chi-square rejects the hypothesis of low explanatory power and the model correctly predicted $85 \%$ of the observations.

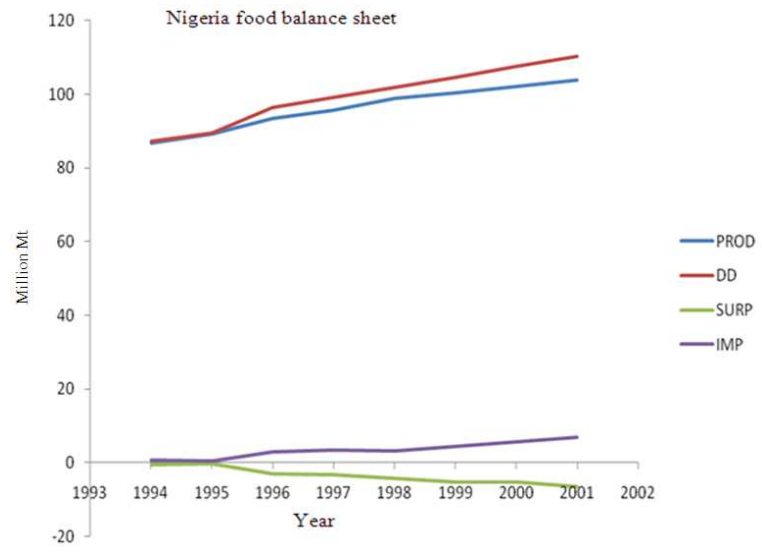

Fig. 1: Nigeria food balance sheet 1994-2001

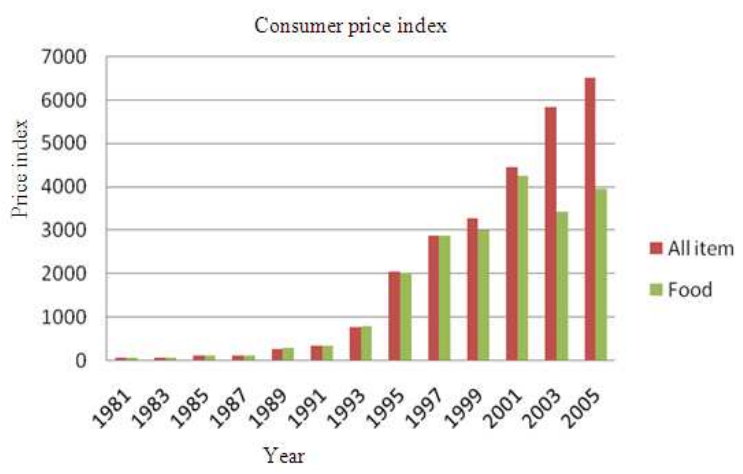

Fig. 2: Composite consumer price index

Table 1: Logistic results of determinant of the food insecurity in households

\begin{tabular}{lcr}
\hline Variables & Coefficients & Wald \\
\hline Constant & -0.484 & 0.081 \\
$\mathrm{AGE}_{\mathrm{H}}$ & -0.002 & 0.002 \\
$\mathrm{SEX}_{\mathrm{H}}$ & -0.311 & 0.199 \\
$\mathrm{EDU}$ & -0.243 & 1.571 \\
$\mathrm{HHS}$ & $-1.083 * * *$ & 17.087 \\
$\mathrm{INC}$ & $0.000 * * *$ & 21.387 \\
$\mathrm{FSC}$ & -0.471 & 1.064 \\
OCC & -2.151 & 3.013 \\
LR statistics & 3.946 & \\
Cox and Snell R & & \\
Log likelihood & 0.513 & \\
\% Correct predictions & 62.639 & \\
\hline
\end{tabular}

The $\mathrm{R}$ square value represented that the model estimated was able to account for $51 \%$ of the variability's of the factors of food insecurity. The logistic result is presented in Table 1.

Result of data analysis: In the result in Table 1, two variables household size and household income per capita were highly significant at $99 \%$ confidence interval in explaining food insecurity. The two variables 
conformed to a priori expectation in sign and magnitude.

Indicators of malnutrition in households: The evident manifestation of food insecurity in children is in terms of their nutritional status. The z-score values of anthropometric assessment of height and weight when compared against a reference population is used to establish incidence of growth retardation, under-weight and stunting in children. To determine the socioeconomic factors that predispose children to these conditions, a multivariate regression analysis was carried out. The results for various indicators are shown in Table 2. Static analysis has shown that short-and long-term determinants of malnutrition consist of a complex set of interacting variables (Okezie and Nwosu, 2007). Von Braun et al. (1991) observed that not only current household-level food availability measured in calorie consumption per capita, that determines children's stunting or wasting as assessed in the anthropometric measurements. They further reported that low levels of food consumption and a poor health situation of children reinforce each other and lead to deterioration of nutritional status. These complexities were addressed in more detail with the help of a multivariate analysis.

Like von Braun et al. (1991) pointed out, it should be noted at the outset that such anthropometric models, which make use of cross-sectional information and short-term-change information over the rather shortterm survey period can only achieve a relatively low level of explanatory power in terms of coefficient of determination $\left(\mathrm{R}^{2}\right)$. Quite commonly, $\mathrm{R}^{2}$ of 0.05 to 0.10 are considered normal or at the higher end for such models. This is so because of numerous factors that cannot be fully captured in such models without a longterm, child-specific database which were obviously not taken into consideration in this study. The $\mathrm{R}^{2}$ values captured to an acceptable level the variability and all the results were true reflections as all the F-values were significant (Table 2).

Height-for-age represents a long-term indicator, as it reflects the past growth of the child, which is the result of numerous factors beginning with birth weight and including morbidity and consumption-deficiency episodes throughout childhood. Weight-for-age represents a long-term and, to some extent, a short-term indicator, as it is related to the child's height and the extent of present undernourishment given a certain height. Weight-for-height indicates a short-term nutritional situation. The expected sign of the age of child could positive or negative. However, in this case it is negative and highly significant in the three indicators.
Table 2: Determinants of incidence of malnutrition among children

\begin{tabular}{llcc}
$\begin{array}{l}\text { Socioeconomic } \\
\text { characteristic }\end{array}$ & $\mathrm{HAZ}$ & $\mathrm{WAZ}$ & $\mathrm{WHZ}$ \\
\hline Constant & $0.117^{* *}$ & $1.407^{* * * *}$ & $0.883^{* * *}$ \\
& -2.361 & -6.822 & -5.019 \\
AGE $_{\mathrm{C}}$ & $-0.292^{* * *}$ & $-0.533^{* * *}$ & $-0.461^{* * *}$ \\
& $(-3.084)$ & $(-6.377)$ & $(-5.019)$ \\
$\mathrm{ILL}$ & 0.099 & 0.086 & 0.052 \\
& -0.998 & -0.989 & -0.052 \\
$\mathrm{SEX}_{\mathrm{C}}$ & -0.054 & $-0.158^{*}$ & -0.096 \\
& $(-0.554)$ & $(-1.853)$ & $(-1.029$ \\
$\mathrm{FEX}$ & -0.085 & -0.097 & 0.000 \\
& $(-0.878)$ & $(-1.140)$ & $(-0.096)$ \\
$\mathrm{HHS}$ & $-0.249 * * *$ & $-0.189 * *$ & 0.014 \\
& $(-2.588)$ & $(-2.231)$ & -0.152 \\
EDU & -0.156 & -0.081 & 0.098 \\
& $(-1.635)$ & $(-0.965)$ & -1.069 \\
BOR & -0.047 & $-0.181^{* *}$ & $-0.216^{* *}$ \\
& $(-0.468)$ & $(-2.052)$ & $(-2.234)$ \\
$\mathrm{R}^{2}$ & 0.198 & 0.376 & 0.256 \\
F- value & $3.236^{* * *}$ & $7.961^{* * *}$ & $4.464^{* * *}$ \\
\hline
\end{tabular}

\section{DISCUSSION}

The performance of the agricultural sector has been uneven in the past. Its average annual growth rate ranges from about $3.3 \%$ in 1990 to an average of $6 \%$ in the past 5 years. Most of the current growth rate has been attributed more to expansion in cultivated land area rather than increase in productivity. Most of the various program and policies enunciated over the years and supported by Donor/Development partners did not also achieve their full development objectives (Akinyele, 2009). The declining contribution of agriculture was not because a strong industrial sector is displacing agriculture but largely as a result of low productivity, owing to the dominance of peasant farmers and their reliance on rudimentary farm equipment and low technology. Another feature of the sector is under-capitalization which results in low yield and declining output, among others. The industrial sector comprises the manufacturing, mining (including crude petroleum and gas) and electricity generation. Prior to independence in 1960, the Nigerian economy was mainly agrarian.

Christiansen et al. (1999) and Ruel et al. (1998) were unanimous on the fact that food security has to do with access of all persons to adequate diet at any point in time to live an active live and healthy life. This can only be guaranteed not only by availability but also by access and utilization (Chung et al., 1997). By implications the food unsecured economy is at the risk of losing availability, which is a function of total food supply, access to food, which is a function of farm-gate prices and utilization, which is a function of nutrient content. The most important limiting factor to food security apart from those related to natural factors are 
high rate of inflation, exchange rate misalignment deteriorating terms of trade, removal of subsidies on agro-allied inputs which have not only inhibited availability but have also restricted the access, (Sen, 1981; Serageldin, 1989; Garrett, 2000; Smith and Haddad, 2000; Wilson, 2001). Other factors may include availability of agricultural resources, inadequate infrastructural facilities and demographic factors (Ayres and McCalla, 1996). The implication of the above analogy is that food prices is a determinant of food security. The rise of food prices over the years overtly manifested in the high incidence food insecurity which manifested in nutritional problems across the country in rural areas (Akinyele, 2009; Malek and Usami, 2009).

Previous studies has shown that average household size in Abia is about six persons (Okezie, 2005). Household heads are under obligation to cater for the material needs of the members and in the midst of other contending demands like payment of school fees and other cares may be under increased pressure of meeting food demands. This portends negative consequences in household that range from school dropouts and juvenile delinquencies. The more people you have in households the more the drain on household resources and the risk of food insecurity becomes high. The result affirms that high numbers of people in household will increase the incidence of food insecurity in households other things being equal as equally reported by Babatunde et al. (2007). Household income is a very important factor in food security studies as it determines access. Food in households come from both own production and market purchases. The higher is ones income the probability that economic access will not be a problem as more votes can be devoted to meeting food demand. The importance of household income is made more manifest by the fact that farm size is not insignificant in the model. The implication is that food from own production does not constitute a significant portion of household food needs. This may not be out context as farming is characterized by the use of obsolete equipment (hoe and cutlass) and decreasing soil fertility arising from continuous cropping and near unavailability of fertilizers.

Age particularly was significant in responding to the three nutritional problems in children. The implication is that as the child grows older the incidence of growth retardation, underweight and wasting will decrease. This likely is attributed to the special emphasis on Baby Friendly Initiative (BFI) that is complete breast feeding for the first six months. Nursing mothers who participate in the problem receive post natal education covering issues on baby care and free medical services in the state. Household size has no significant impact on wasting/stunting in children while it is significant in accounting for manifestation of growth retardation and underweight in children .Large households sizes in the study all things being equal will continue to expose children to nutritional problems of growth retardation and stunting. It is interesting to note that birth order has influence on the short-term indicator stunting. As the number of children increase in the household financial pressure increase and if there is no commensurate increase in income there is incremental marginalization of the subsequent ones, as child care may decrease.

\section{CONCLUSION}

Inconsistent food security results in inadequate dietary intake, which leads to malnutrition. Malnutrition is the most serious consequence of food insecurity. Adult malnutrition results in a lower productivity on farms and in the labor market. In women, it also results in fetal malnutrition and low birth weights. Fetal and infant under nutrition leads to lower cognitive development and poor schooling performance. For school-age children, nutritional deficiencies are responsible in part for poor school enrollment, absenteeism, early dropout and poor classroom performance with consequent losses in productivity during adulthood.

\section{REFERENCES}

Abdullateef, U. and A. Ijaiya, 2010. Agricultural trade liberalization and food security in Nigeria. J. Econ. Int. Finance, 2: 299-307.

Akinyele, I.O., 2009. Ensuring Food and Nutrition Security in Rural Nigeria: An Assessment of the Challenges, Information Needs and Analytical Capacity. Nigeria Strategy Support Program (NSSP). Background Papre No 007. International Food Policy Research Institute, Washington DC.

Ayres, W.S. and A.F. McCalla, 1996. Rural development, agriculture and food security. IMF/World Bank Finance Dev., 33: 8-11.

Babatunde, R.O., O.A. Omotsho and O.S. Sholatan, 2007. Socioeconomic characteristics and Food Security of Farming households in Kwara State, North-Central Nigeria. Pak. J. Nutr., 6: 49-58.

Christiansen, L.J., R.N. Boisvert and J. Hodinott, 1999. Validating Operational Food Insecurity Indicators against a Dynamic benchmark: Evidence from Mali. Res. Work. Papers, 1-29. DOI: $10.1596 / 1813-9450-2471$ 
Christopher, G., V. Limsombunchai, M. Clemes and A. Weng, 2005. Consumer choice prediction: Artificial neural networks versus logistic models. J. Soc. Sci., 1: 211-219. DOI: 10.3844/jssp.2005.211.219

Chung, K., L. Haddad, J. Ramakrishna and F. Riley, 1997. Alternative Approaches to Locating the Food Insecure: Qualitative and Quantitative Evidence from South India. International Food Policy Research Institute, FCND Discussion Papers, pp: 110.

Garrett, J.L., 2000. Achieving Urban Food and Nutrition Security in the Developing World: A 2020 Vision for Food, Agriculture and the Environment. Washington DC: International Food Policy Research Institute.

Ghaly, E. and F. N. Alkoaik, 2010. Extraction of protein from common plant leaves for use as human food. Am. J. Applied Sci., 7: 331-342. DOI: 10.3844/ajassp.2010.331.342

Iraj, M., 2009. Toward clean green sustainable development to prevent the first food world war, changing authoritative-public extension to literalized-partnership extension system . Am. J. Agric. Biol. Sci., 4: 49-62. DOI: 10.3844/ajabssp.2009.49.62

Jampawai, S., S. Pothinam, M. Kanato, P. Tongkrajai and P. Homjumpa, 2011. Model development for health promotion in the elderly participating in communities. Am. J. Applied Sci., 8: 843-847. DOI: 10.3844/ajassp.2011.843.847

Malek, M.A. and K. Usami, 2009. Determinants of nonfarm income diversification in developed villages of Bangladesh. Am. J. Econ. Bus. Admin., 1: 141149. DOI: 10.3844/ajebasp.2009.141.149

Mamoun, N., S. Homedia, M. Mabyou and H.M.A. Muntasir, 2006. Prevalence, types and risk factors for malnutrition in displaced sudanese children. Am. J. Infect. Dis., 1: 84-86. DOI: 10.3844/ajidsp.2005.84.86

Okezie, C.A. and A.C. Nwosu, 2007. The effect of agricultural commercialization on the nutritional status of cocoa growing households in Ikwuano L.G.A of Abia State, Nigeria. Int. J. Agric. Rural Dev., 9: 12-15. ISSN: ISSN: 1595-9716

Okezie, C.A., 2005. Effects of agricultural commercialization on production, consumption and nutrition in farm household, in Abia State. Ph.D Dissertation Michael Okpara University of Agriculture, Umudike, Nigeria.
Okwu, G.N., A.I. Ukoha, N. Nwachukwu, N.C. Agha, 2008. Studies on the predisposing factors of protein energy malnutrition among pregnant women in a Nigerian community. Online J. Health Allied Sci., 6: $1-10$.

Oluwatayo, I.B., 2008. Explaining inequality and welfare status of households in rural Nigeria: Evidence from Ekiti State. Hum. Soc. Sci. J., 3: 7080 .

Ruel, M.T, J.L.Garrett , S.S. Morries, D. Maxwell and A. Oshaug et al., 1998. Urban Challenges to Food and Nutrition Security: A Review of Food Security, Health and Care giving in the Cities. International Food Policy Research Institute, Washington, DC 20006, USA.

Sanusi, R.A. and B.C. Adebukola and Y.B. Oyindamola, 2006. Measuring household food insecurity in selected local government areas of Lagos and Ibadan, Nigeria. Pak. J. Nutr., 5: 62-67. DOI: $10.3923 /$ pjn.2006.62.67

Sen, A.K., 1981. Poverty and Famines: An Essay on Entitlement and Deprivation. 1st Edn., Oxford University Press, Oxford, ISBN: 0198284632, pp: 257.

Serageldin, I., 1989. Poverty, Adjustment and Growth in Africa Washington DC: The World Bank.

Shahateet, M.I., 2007. The determinants of deprivation in Jordan: Empirical study. J. Soc. Sci., 3: 36-42. DOI: $10.3844 /$ jssp.2007.36.42

Smith, L.C. and L. Haddad, 2000. Overcoming Child Malnutrition in Development Countries: Past Achievement and Future Choices. International Food Policy Research Institute, Food, Agriculture and Environment Discussion Paper No 30, pp: 53. ISBN: 0896296342

Von Braun, J., H. Haen and J. Blanken, 1991. Commercialization of agriculture under population pressure. Effects on Production, Consumption and Nutrition in Rwanda, Research Report 85. International Food Policy Research Institute.

Wilson, E., 2001. Urbanization and Agriculture to the year 2020. In: The Unfinished Agenda: Perspectives on Overcoming Hunger, Poverty and Environmental Degradation 2001, PinstrupAndersen, P. and R. Pandya-Lorch (Eds.). International Food Policy Institute, Washington D.C., pp: 73-77. ISBN: 0-89629-706-3 